\title{
Antioxidant Effect and Functional Properties of Hydrolysates Derived from Egg-White Protein
}

\author{
Dae-Yeon $\mathrm{Cho}^{1}$, Kyungae $\mathrm{Jo}^{2}$, So Young $\mathrm{Cho}^{2}$, Jin Man $\mathrm{Kim}^{3}$, Kwangsei Lim${ }^{4}$, \\ Hyung Joo Suh ${ }^{2,5, *}$, and Sejong Oh* \\ Division of Animal Science, Chonnam National University, Gwangju 500-757, Korea \\ ${ }^{1}$ Comimax Co. Ltd., Seoul 139-860, Korea \\ ${ }^{2}$ Department of Food and Nutrition, Korea University, Seoul 136-703, Korea \\ ${ }^{3}$ Department of Food Science and Biotechnology of Animal Resources, Konkuk University, Seoul 143-701, Korea \\ ${ }^{4}$ Dairy Food R\&D Center, Maeil Dairies Co., Ltd. Pyungtaek 451-861, Korea \\ ${ }^{5}$ BK21PLUS Program in Embodiment: Health-Society Interaction, Department of Public Health Science, \\ Graduate School, Korea University, Seoul 136-703, Korea
}

\begin{abstract}
This study utilized commercially available proteolytic enzymes to prepare egg-white protein hydrolysates (EPHs) with different degrees of hydrolysis. The antioxidant effect and functionalities of the resultant products were then investigated. Treatment with Neutrase yielded the most $\alpha$-amino groups $(6.52 \mathrm{mg} / \mathrm{mL})$. Alcalase, Flavourzyme, Protamex, and Ficin showed similar degrees of $\alpha$-amino group liberation $(3.19-3.62 \mathrm{mg} / \mathrm{mL})$. Neutrase treatment also resulted in the highest degree of hydrolysis (23.4\%). Alcalase and Ficin treatment resulted in similar degrees of hydrolysis. All hydrolysates, except for the Flavourzyme hydrolysate, had greater radical scavenging activity than the control. The Neutrase hydrolysate showed the highest 2,2-azino-bis-(3-ethylbenzothiazoline-6-sulfonic acid) (ABTS) radical scavenging activity $\left(\mathrm{IC}_{50}=3.6\right.$ $\mathrm{mg} / \mathrm{mL}$ ). Therefore, Neutrase was identified as the optimal enzyme for hydrolyzing egg-white protein to yield antioxidant peptides. During Neutrase hydrolysis, the reaction rate was rapid over the first $4 \mathrm{~h}$, and then subsequently declined. The $\mathrm{IC}_{50}$ value was lowest after the first hour $(2.99 \mathrm{mg} / \mathrm{mL})$. The emulsifying activity index (EAI) of EPH treated with Neutrase decreased, as the $\mathrm{pH}$ decreased. The EPH foaming capacity was maximal at $\mathrm{pH} 3.6$, and decreased at an alkaline $\mathrm{pH}$. Digestion resulted in significantly higher 1,1-diphenyl-2-picrylhydrazyl (DPPH) and ABTS radical scavenging activity. The active peptides released from egg-white protein showed antioxidative activities on ABTS and DHHP radical. Thus, this approach may be useful for the preparation of potent antioxidant products.
\end{abstract}

Key words: egg-white protein, hydrolysate, Neutrase, radical scavenging activity, functionality

\section{Introduction}

Hen eggs are a traditional food used in many basic and formulated preparations and have excellent nutritive value. The egg has a significant reserve of highly digestible proteins, lipids, vitamins, and minerals as well as other molecules with health-promoting properties. More-

\footnotetext{
*Corresponding author: Hyung Joo Suh, BK21PLUS Program in Embodiment: Health-Society Interaction, Department of Public Health Science, Graduate School, Korea University, Seoul 136-703, Korea. Tel: +82-2-940-2853, Fax: +82-2-940-2859, Email: suh1960@korea.ac.kr

*Corresponding author: Sejong Oh, Division of Animal Science, Chonnam National University, Gwangju 500-757, Korea. Tel: +82-62-530-2116, Fax: +82-62-530-2129, E-mail: soh@chonnam.ac.kr
}

over, the egg contains molecules that can be exploited for biotechnological purposes (Anton et al., 2006). Over the last decade, numerous studies have characterized the biophysiological functions of egg components and have identified novel biologically active substances (Mine, 2007). As such, eggs have been recognized as a source of biologically active substances with significant therapeutic potential.

The application of egg in food preparation depends primarily on its protein properties. Many attempts have been made to develop chemical or enzymatic modifications that alter functional characteristics of egg white protein (Kato et al., 1989; Matsudomi et al., 1991). The proteolytic enzyme such as papain is capable of breaking down larger molecules of protein into smaller constituents. Papain has been used to prepare resynthesized protein hyd- 
rolysates (Edwards and Shipe, 1978).

Sakanaka et al. (2004) found that the egg-yolk protein hydrolysates, when compared with its original protein or amino acids mixture, showed stronger antioxidant activity in a linoleic acid oxidation system. Peng et al. (2009) used alcalase to hydrolyze whey protein isolate, obtaining a hydrolysate fraction that possessed strong scavenging activities on DPPH, hydroxyl and superoxide radicals. Similarly, Li et al. (2008) reported that chickpea hydrolysates possess a scavenging ability on superoxide anions. What is more, protein hydrolysates present nutritional and functional properties beside their antioxidant activity (Chen et al., 2012; Xie et al., 2008). These food-derived antioxidants are considered to be safe and free ofside effects, which may be occurred in the synthetic antioxidants.

Preparative process for bioactive peptides potentially influences the molecular size, hydrophobicity and polar groups of the hydrolysate (Adler-Nissen, 1979; Kristinsson and Rasco, 2000). These alterations in of hydrolysate characteristics directly affect the functional properties, physical activities, and the uses as food ingredients (Kristinsson and Rasco, 2000). Hydrolysates from different protein sources, such as whey, soy (Pena-Ramos and $\mathrm{Xi}$ ong, 2003), egg-yolk, prawn (Suetsuna, 2000), tuna cooking juice (Jao and Ko, 2002), yellowfin sole frame (Jun et al., 2004), and capelin (Amarowicz and Shahidi, 1997), have been known to possess antioxidant activity. Levels and compositions of free amino acids and peptides were reported to determine the antioxidant activities of protein hydrolysates (Wu et al., 2003). In addition, a recent study reported the antioxidant activity of peptides which are produced from crude egg white by pepsin treatment (Davalos et al., 2004). Nevertheless, information on functional properties and antioxidant activity of peptides produced from enzyme hydrolysis is still limited to be understood. If functional properties of peptides depend on the amino acid compositions of peptides, proteolytic enzymes are expected to produce various peptides, which have different amino acid compositions, functionalities, and antioxidant activities. Accordingly, it would be valu- able to determine the effects of each proteolytic enzymes on functionalities and antioxidant activity of the egg white hydrolysates.

This study was conducted in order to prepare antioxidant peptides from egg white using commercial proteases. In addition, physicochemical properties of egg white peptides were also analyzed.

\section{Materials and Methods}

\section{Chemicals and enzymes}

L-Leucine, 2,4,6-trinitrobenzenesulphonic acid (TNBS), 1,1-diphenyl-2-picrylhydrazyl (DPPH), and 2,2-azino-bis(3-ethylbenzothiazoline-6-sulfonic acid) (ABTS) were purchased from Sigma-Aldrich (USA).

Alcalase, Neutrase, Flavourzyme, and Protamex were purchased from Novozymes (Bagsvaerd, Denmark). Collupulin was purchased from DSM Corp. (Heerlen, Netherlands). Papaya and Ficin were purchased from Sigma Co. (USA). The characteristics of each enzyme are summarized in Table 1. All chemicals were of analytical grade.

\section{Preparation of EPH and in vitro digestion}

Egg-white powder (Edentown FnB, Korea) (10 g) was mixed with $100 \mathrm{~mL}$ deionized water and $\mathrm{pH}$ adjusted to 6.0 with $0.1 \mathrm{~N} \mathrm{NaOH}$. The suspension was preincubated at $45^{\circ} \mathrm{C}$ for $20 \mathrm{~min}$ prior to enzymatic hydrolysis using various proteases and then hydrolyzed for $12 \mathrm{~h}$. The hydrolysis conditions are reported in Table 1. After hydrolysis, the enzymes were inactivated by boiling for 15 min. The hydrolysates were centrifuged in a refrigerated centrifuge (Beckman model J2-21, Beckman Coulter, INC., USA) at $2,800 \mathrm{~g}$ for $20 \mathrm{~min}$, and the supernatants were lyophilized (TFD, Ilshin, Korea) and stored in a desiccator before further use. Non-enzymatic hydrolysis was used as control.

To mimic in vivo digestion process, an in vitro digestion model system using enzymes similar to those in the upper gastrointestinal digestive tract of humans was used.

Table 1. Enzyme characteristics

\begin{tabular}{|c|c|c|c|c|}
\hline \multirow{2}{*}{ Enzyme } & \multirow{2}{*}{ Source } & \multicolumn{2}{|c|}{ Optimum condition } & \multirow{2}{*}{ Type } \\
\hline & & Temperature $\left({ }^{\circ} \mathrm{C}\right)$ & $\mathrm{pH}$ & \\
\hline Alcalase & Bacillus sp. & $50-60$ & $8.0-9.0$ & Endo \\
\hline Neutrase & B. amyloliquefaciens & 45 & $6.0-7.0$ & Endo \\
\hline Protamex & Bacillus sp. & $35-60$ & $5.5-7.5$ & Complex \\
\hline Flavourzyme & Aspergillus sp. & $45-50$ & $5.0-7.0$ & Complex \\
\hline Collupulin & Caruca papaya & $50-70$ & $5.0-7.5$ & Endo \\
\hline Ficin & Ficus carica & $45-55$ & $5.0-6.0$ & Endo \\
\hline
\end{tabular}


In vitro digestion of EPH prepared with Neutrase was carried out by the modified method of Miguel et al. (2007). Two grams of EPH was dissolved in $80 \mathrm{~mL}$ Milli-Q water and adjusted to $\mathrm{pH} 2.0$ with $1 \mathrm{M} \mathrm{HCl}$. Hydrolysis with pepsin (EC 3.4.23.1 type A, 10,000 U/mg from pork stomach obtained from Sigma Chemical Co., St. Louis, $\mathrm{MO}$;; E/S 1/50, wt/wt) was carried out at $37^{\circ} \mathrm{C}$ for $2 \mathrm{~h}$. Inactivation of pepsin was achieved by increasing the $\mathrm{pH}$ to 7.0 with $0.5 \mathrm{M} \mathrm{NaHCO}_{3}$.

After neutralization, pancreatic digestion (from porcine gastric mucosa, Sigma Chemical Co.) was conducted at an enzyme:substrate ratio of 1:50 w/w at $\mathrm{pH} 7.0-8.0$ and $37^{\circ} \mathrm{C}$ for $150 \mathrm{~min}$ with continuous stirring. The reaction was stopped by heating to $95^{\circ} \mathrm{C}$ for $10 \mathrm{~min}$ in a water bath followed by cooling to room temperature. The sample was used for measuring radical scavenging activity.

\section{Quantification of $\alpha$-amino acids and degree of hydrolysis}

The $\alpha$-amino acid content was determined according to the method of Benjakul and Morrissey (1997). To the diluted protein hydrolysate samples $(125 \mu \mathrm{L}), 2.0 \mathrm{~mL}$ of 212.5 $\mathrm{mM}$ phosphate buffer, $\mathrm{pH} 8.2$, and $1.0 \mathrm{~mL}$ of $0.01 \%$ TNBS solution were added. The solution was mixed thoroughly and placed in a $50^{\circ} \mathrm{C}$ water bath (Model W350, Memmert, Germany) for $30 \mathrm{~min}$ in the dark. The reaction was terminated by the addition of $2.0 \mathrm{~mL}$ of $0.1 \mathrm{M}$ sodium sulfite. The mixtures were cooled at room temperature for $15 \mathrm{~min}$. The absorbance was measured at $420 \mathrm{~nm}$, and $\alpha$-amino acid content was expressed in terms of L-leucine. The DH was calculated as follows (Benjakul and Morrissey, 1997):

$$
\mathrm{DH}=\left[\left(\mathrm{L}_{\mathrm{t}}-\mathrm{L}_{\mathrm{o}}\right) /\left(\mathrm{L}_{\max }-\mathrm{L}_{\mathrm{o}}\right)\right] \times 100
$$

where $\mathrm{L}_{t}$ is the amount of $\alpha$-amino acid released at time t. $\mathrm{L}_{\mathrm{o}}$ is the $\alpha$-amino acid content in the initial egg-white powder. $\mathrm{L}_{\max }$ is total $\alpha$-amino acid content in the original egg-white powder obtained after acid hydrolysis $(6 \mathrm{M} \mathrm{HCl}$ at $100^{\circ} \mathrm{C}$ for $24 \mathrm{~h}$ ).

\section{Free radical-scavenging activity}

DPPH and ABTS were used to determine the free radical-scavenging activities of hydrolysate. The DPPH-scavenging activity was measured using the method described by Quang et al. with slight modifications (Quang et al., 2003). ABTS radical-scavenging activity was determined as described by Wang et al. (2001) and Almajano et al. (2007) with slight modifications. The antioxidant activi- ties of the test samples were expressed as $\mathrm{IC}_{50}$ (i.e., the amount of tested extract required for a $50 \%$ decrease in the absorbance of DPPH and ABTS radicals).

\section{Solubility}

The solubility of each EPH was measured using the procedure of Morr (1985) with slight modifications. Each $\mathrm{EPH}$ was dissolved in $50 \mathrm{~mL}$ of $50 \mathrm{mM}$ citrate- $\mathrm{NaOH}$ buffer ( $\mathrm{pH}$ 3.6), phosphate buffer ( $\mathrm{pH} 7.6$ ), and Tris-HCl buffer ( $\mathrm{pH}$ 9.0). The mixture was stirred at room temperature for $1 \mathrm{~h}$ and centrifuged at 2,800 $\mathrm{g}$ for $30 \mathrm{~min}$ using a Sorvall Model RC-5B Plus centrifuge (Newtown, CT, USA). The protein content of the supernatant was quantified using the bicinchoninic acid method according to the manufacturer's instructions (Pierce Chemicals Ltd, Rockford, USA) using bovine serum albumin as a standard. Total protein content in the sample was determined after solubilization of the sample in $0.5 \mathrm{~N} \mathrm{NaOH}$. Protein solubility was calculated as follows:

$$
\text { Solubility }(\%)=\frac{\text { protein content in supernatant }}{\text { total protein content in sample }} \times 100
$$

\section{Emulsifying properties}

The emulsifying activity index (EAI) at various $\mathrm{pH}$ values was measured by the turbidimetric method described by Pearce and Kinsella (1978). To form an emulsion, a $1.0 \%(\mathrm{w} / \mathrm{v})$ sample was dissolved in $50 \mathrm{mM}$ citrate- $\mathrm{NaOH}$ buffer ( $\mathrm{pH}$ 3.6), phosphate buffer ( $\mathrm{pH}$ 7.6), and Tris-HCl buffer ( $\mathrm{pH}$ 9.0). Twelve milliliters of the dissolved sample and $4 \mathrm{~mL}$ corn oil were homogenized in a blender (IKA Labortechnik, T25B, Germany) at 12,000 rpm for $1 \mathrm{~min}$. A $50-\mu \mathrm{L}$ aliquot of the emulsion was taken from the bottom container at different time intervals and diluted in 5 $\mathrm{mL}$ of $0.1 \%$ sodium dodecyl sulfate. The absorbance of the dilute emulsion was measured at $500 \mathrm{~nm}$. All the experiments were conducted at room temperature. EAI was calculated according to the following equation:

$$
\operatorname{EAI}\left(\mathrm{m}^{2} / \mathrm{g}\right)=\frac{(2 T \times D)}{\left(\phi \times C \times 10^{4}\right)}=\frac{(4.606 \times A \times D)}{\left(\phi \times C \times L \times 10^{4}\right)}
$$

Where $\mathrm{T}$ is the turbidity, $\mathrm{D}$ is the dilution factor, $\phi$ is the volume fraction of the dispersed phase (oil), $\mathrm{C}$ is protein weight per volume of aqueous phase before the emulsion, A is the observed absorbance, and L is the path length of the cuvette.

\section{Foaming properties}

Foaming capacity (FC) and stability (FS) of the sam- 
ples were measured according to the method described by Sathe and Salunkhe (1981). A 1.0\% (w/v) sample was dissolved in $50 \mathrm{mM}$ citrate- $\mathrm{NaOH}$ buffer ( $\mathrm{pH} 3.6$ ), phosphate buffer ( $\mathrm{pH} 7.6)$, and Tris-HCl buffer ( $\mathrm{pH} 9.0)$ and then whipped for $2 \mathrm{~min}$ at 10,000 rpm in a blender (IKA Labortechnik, T25B, Germany). The whipped sample was immediately transferred into a graduated cylinder, and the total volume was measured after $30 \mathrm{~s}$. The foaming capacity was calculated according to the following equation:

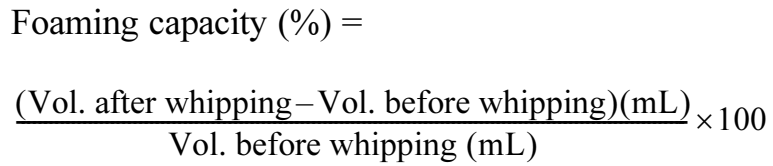

The whipped sample was allowed to stand at $20^{\circ} \mathrm{C}$ for $3 \mathrm{~min}$, and then the volume of whipped sample was recorded. Foam stability was calculated as follows:

$$
\begin{aligned}
& \text { Foam stability }(\%)= \\
& \frac{(\text { Vol. after whipping }- \text { Vol. before whipping })(\mathrm{mL})}{\text { Vol. before whipping }(\mathrm{mL})} \times 100
\end{aligned}
$$

\section{Statistical analysis}

All experiments were carried out in triplicate. Data were analyzed using analysis of variance (ANOVA), and mean comparisons were performed using Duncan's multiple range tests. The difference in radical scavenging activity before and after digestion was tested for statistical significance by a Student's $t$-test. Analysis was performed using SPSS software (SPSS 10.0 for windows, SPSS Inc., USA).

\section{Results and Discussion}

\section{Enzymatic hydrolysis of egg-white protein}

The goal of the present study was to maximize hydrolysis of the substrate and to characterize the hydrolysate. Hydrolysis was monitored by measuring the $\alpha$-amino nitrogen $(A-N)$ content of the supernatant after centrifugation and measuring the $\mathrm{DH}$.

The concentration of $\alpha$-amino groups in the hydrolysate indicates the amount of peptide bonds broken during the hydrolysis reaction (Aspmo et al., 2005). Fig. 1 shows that Neutrase treatment yielded the highest $\alpha$-amino groups $(6.52 \mathrm{mg} / \mathrm{mL})(p<0.05)$, while the control (no enzymatic hydrolysis) showed the lowest level of $\alpha$-amino group liberation $(2.02 \mathrm{mg} / \mathrm{mL})$. Treatment with Alcalase, Flavourzyme, Protamex, and Ficin resulted in similar degrees of $\alpha$-amino group liberation $(3.19-3.62 \mathrm{mg} / \mathrm{mL})$.

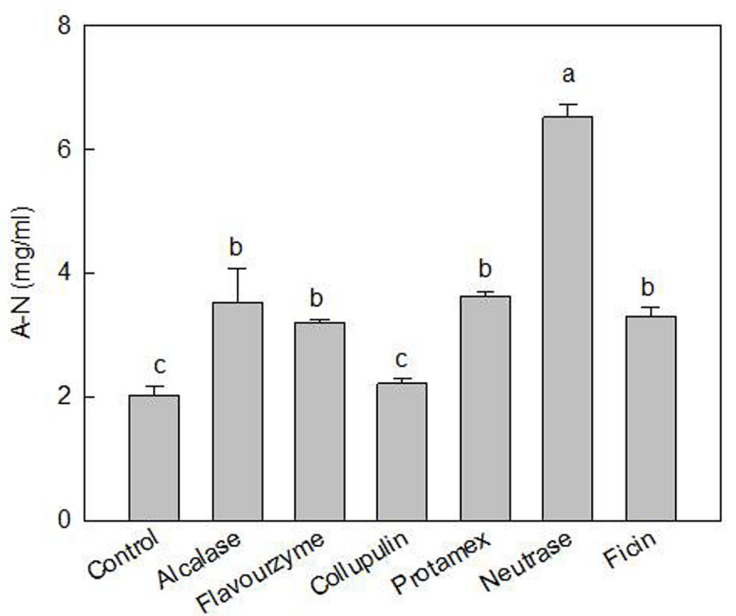

Fig. 1. $\alpha$-amino nitrogen content of egg white hydrolysates made with various proteases. These values are means \pm S.D. Different letters indicate significant differences among the control and six protease treatments $(p<0.05)$.

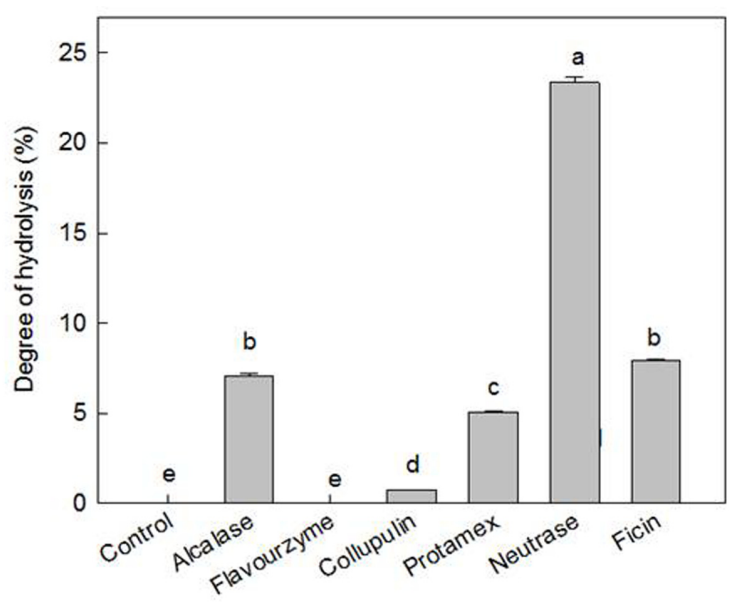

Fig. 2. DH of EPH made with various proteases. These values are mean \pm S.D. Different letters indicate significant differences with the same protease $(p<0.05)$.

The DH is a measure of the extent of hydrolytic degradation of a protein and is the most widely used indicator for comparing different proteolytic processes. A higher DH indicates increased hydrolysis of the egg-white protein. Neutrase treatment resulted in the highest DH level (23.4\%) $(p<0.05)$. Alcalase and Ficin treatments showed similar DH levels (Fig. 2). Although many factors affected DH, the type of enzyme markedly affected the DH and properties of the final product. Therefore, the hydrolytic efficiency of Neutrase was higher than those of the other proteases tested. Therefore, Neutrase may be ideal for use in commercial operations due to its low cost and its high $\alpha$ amino protein recovery. 


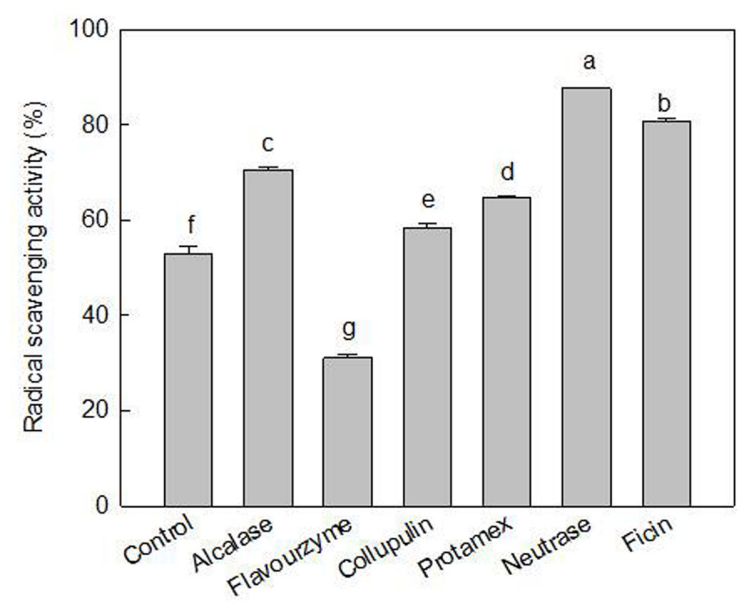

Fig. 3. Radical scavenging activities of EPH made with various proteases. These values are means \pm S.D. Different letters indicate significant differences with the same protease $(p<0.05)$.

Neutrase is an endopeptidase produced from Bacillus amyloliquefaciens. The enzyme has been reported as a potent proteinase for hydrolyzing muscle proteins as well as agricultural waste (Hoyle and Merritt, 1994; Quaglia and Orban, 1987).

\section{Radical scavenging activity of EPH}

Enzymatic hydrolysis of food proteins is an efficient method of recovering potent bioactive peptides. Protein hydrolysates from plant and animal sources have strong antioxidant activities. $\mathrm{ABTS}^{+}$radical scavenging activity is a widely used assay of antioxidant activity and can be applied to both lipophilic and hydrophilic compounds (Miliauskas et al., 2004).

As shown in Fig. 3, the control showed a radical scavenging activity of $52.8 \%$ at a concentration of $7.5 \mathrm{mg} / \mathrm{mL}$. All hydrolysates except the Flavourzyme hydrolysate showed higher radical scavenging activity than the control. In particular, the Neutrase hydrolysate had the highest radical scavenging activity $(87.75 \%)$ at a concentration of $7.5 \mathrm{mg} / \mathrm{mL}$. The $\mathrm{IC}_{50}$ value of the Neutrase hydrolysate was $3.6 \mathrm{mg} / \mathrm{mL}$ for the ABTS radical. This indicated that limited hydrolysis of egg-white protein resulted in improved antioxidant activity than extensive hydrolysis. Similarly, Wang and Xiong (2005) reported that heat-coagulated potato protein had improved ABTS radical scavenging activity at a $\mathrm{DH}$ of $1.9 \%$ than at a $\mathrm{DH}$ of $0.72 \%$ or $2.3 \%$. The difference might be attributed to the specific peptide/amino acid composition (Wu et al., 2003). The results suggested that loach protein hydrolysate prepared by papain at appropriate DH (23-33\%) had more active amino acids or peptides, which could react with free radicals to form more stable products, compared with Protamex.

The antioxidant activity of protein hydrolysates depends on the proteases (Jun et al., 2004) and hydrolysis conditions (Jao and Ko, 2002; Jun et al., 2004). During hydrolysis, a variety of smaller peptides and free amino acids are generated depending on enzyme specificity. Changes in the size, quantity, and composition of free amino acids and small peptides also affect the antioxidant activity (Wu et al., 2003). Jun et al. (2004) reported that yellowfin sole hydrolysate prepared using pepsin at the lowest DH (22\%) had a higher antioxidant activity than hydrolysates produced using other enzymes, such as Alcalase, $\alpha$ chymotrypsin, papain, pepsin, Pronase E, Neutrase, and trypsin.

Raghavan et al. (2008) also reported that low molecular weight (LMW) peptides had a high ability to scavenge ROS generated by mononuclear cells. Hydrolysates prepared using Neutrase had a high level of LMW even at $7.5 \% \mathrm{DH}$ (as compared to the other four enzymes), and were effective scavengers of ROS. Several researchers have reported the radical scavenging ability of LMW peptides from casein (Suetsuna, 2000), soy proteins (Moure et al., 2006), chick peas (Quang et al., 2003), and several other hydrolysates. The antioxidant activity has been attributed to the presence of free amino acids and small peptides, which can effectively scavenge radicals.

These results revealed that EPH contained substances that acted as electron donors and reacted with free radicals to terminate the radical chain reaction and convert them to more stable products. Based on our results, we selected Neutrase as the optimal enzyme to hydrolyze egg-white protein for generating antioxidant peptides.

\section{DH, A-N content, and ABTS radical scavenging activity during neutrase hydrolysis}

During Neutrase hydrolysis of egg-white protein, the reaction rate was rapid in the first $4 \mathrm{~h}$ and subsequently decreased. After $4 \mathrm{~h}$, the rate remained constant, suggesting that the enzymatic reaction reached a steady state (Fig. 4(A)). This pattern is typical of hydrolysis curves reported for fish protein and whey protein (Kristinsson and Rasco, 2000; Mutilangi et al., 1996). The hydrolytic curve of wheat gluten (Kong et al., 2007) was also similar to that shown in Fig. 4, with $\mathrm{DH}$ values ranging from $0 \%$ to $27.2 \%$ during $24 \mathrm{~h}$ of incubation.

A similar curve was reported for the enzymatic hydrolysis of crayfish (Baek and Cadwallader, 1995), capelin 

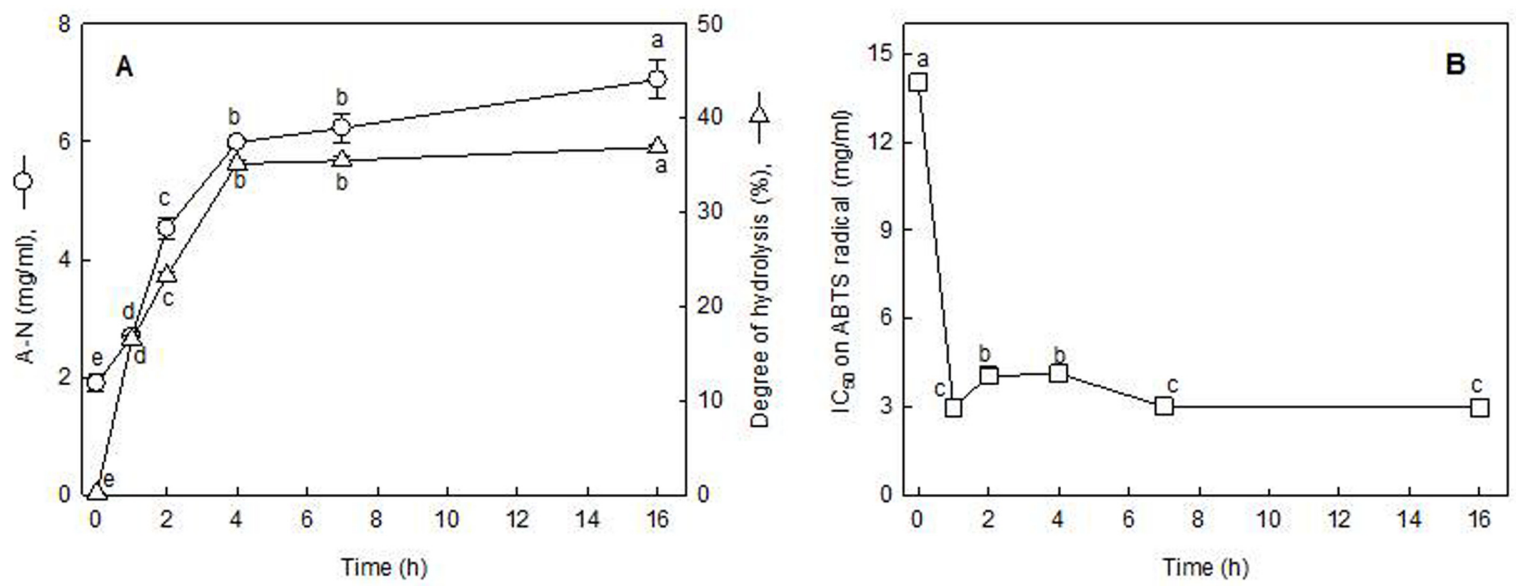

Fig. 4. Changes in A-N content and DH of EPH during Neutrase hydrolysis. These values are means \pm S.D. Different letters indicate significant differences with the same protease $(p<0.05)$.

(Shahidi et al., 1995), sardine (Quaglia and Orban, 1987), and veal-bone byproducts (Linder et al., 1996). Generally, the enzyme rapidly adsorbs onto the insoluble protein particles, and then polypeptide chains loosely bound to the surface are cleaved. The more compact core proteins are hydrolyzed more slowly. The rate of enzymatic cleavage of peptide bonds controls the overall rate of hydrolysis (Archer et al., 1973).

Fig. 4(B) shows changes in ABTS radical scavenging activity. The $\mathrm{IC}_{50}$ value was lowest during the first $1 \mathrm{~h}$ of hydrolysis $(2.99 \mathrm{mg} / \mathrm{mL})$. Thereafter, the $\mathrm{IC}_{50}$ value slightly increased until $7 \mathrm{~h}$ and subsequently declined (Fig. 4(B)).

Based on our assessment of radical scavenging activity, we concluded that EPH contained antioxidant peptides that could convert free radicals into more stable products and terminate the radical chain reaction. Moreover, the optimal reaction conditions for Neutrase hydrolysis were near physiological conditions ( $\mathrm{pH} 7.0$ and $37^{\circ} \mathrm{C}$ ), which may decrease the processing cost. Therefore, we chose Neutrase as the optimal enzyme to hydrolyze egg-white protein for the generation of antioxidant peptides. The preparation procedure resulted in a dry weight yield of $64.5 \%$ (data not shown).

\section{Functionality of EPH prepared with Neutrase}

The functional properties of proteins can be modified by changing their structure through physical, chemical, and enzymatic treatment. Hydrolysis affects the molecular size, hydrophobicity, and polar-group content of the hydrolysate (Kristinsson and Rasco, 2000). The hydrolysate's characteristics directly affect its functional properties and potential use as a food ingredient (Kristinsson and Rasco, 2000).
The solubility of EPH was high at a basic $\mathrm{pH}$, gradually decreased with decreasing $\mathrm{pH}$, and was very low at $\mathrm{pH} 3$ (Fig. 5(A)). Neutrase hydrolysis showed the increase of solubility compared with non-hydrolysis egg white powder. This suggests that there is a high degree of aggregation at $\mathrm{pH}$ 3. Shen (1976) reported that at high $\mathrm{pH}$, in addition to denaturation, other reactions occur that enhance peptide solubility.

EAI decreased with decrease in pH (Fig. 5). The solubility was lowest at $\mathrm{pH} 4$; therefore, the peptides could not move rapidly to the interface, and their net charge was minimized. EAI was a similar capacity at $\mathrm{pH} 3.6$ and 9.0. However, Neutrase hydrolysate showed a significantly higher EAI than non-hydolysis of egg white powder at $\mathrm{pH} 7.6(p<0.05)$.

In order to produce an emulsion, a new interface must be produced by lowering the internal free energy, and there must be an adsorbed layer at the oil/water interface (Hill, 1996). According to Li-Chan and Nakai (1990), the ability of a protein to interact with oil or other protein molecules and form an interfacial layer depends on its flexibility and the accessibility of surface-exposed groups. These features are particularly important for hydrophobic interactions.

Peptides with low molecular weights had low amphiphilicity, which is required for producing an emulsion. Turgeon et al. (1991) also reported that hydrolysis dramatically reduced a peptide's emulsifying properties. Although small peptides diffuse rapidly toward the interface, they are less efficient at stabilizing emulsions, because they may not readily agglomerate to produce a fat-globule membrane due to charge repulsions.

The foaming properties of EPH were affected by $\mathrm{pH}$. 

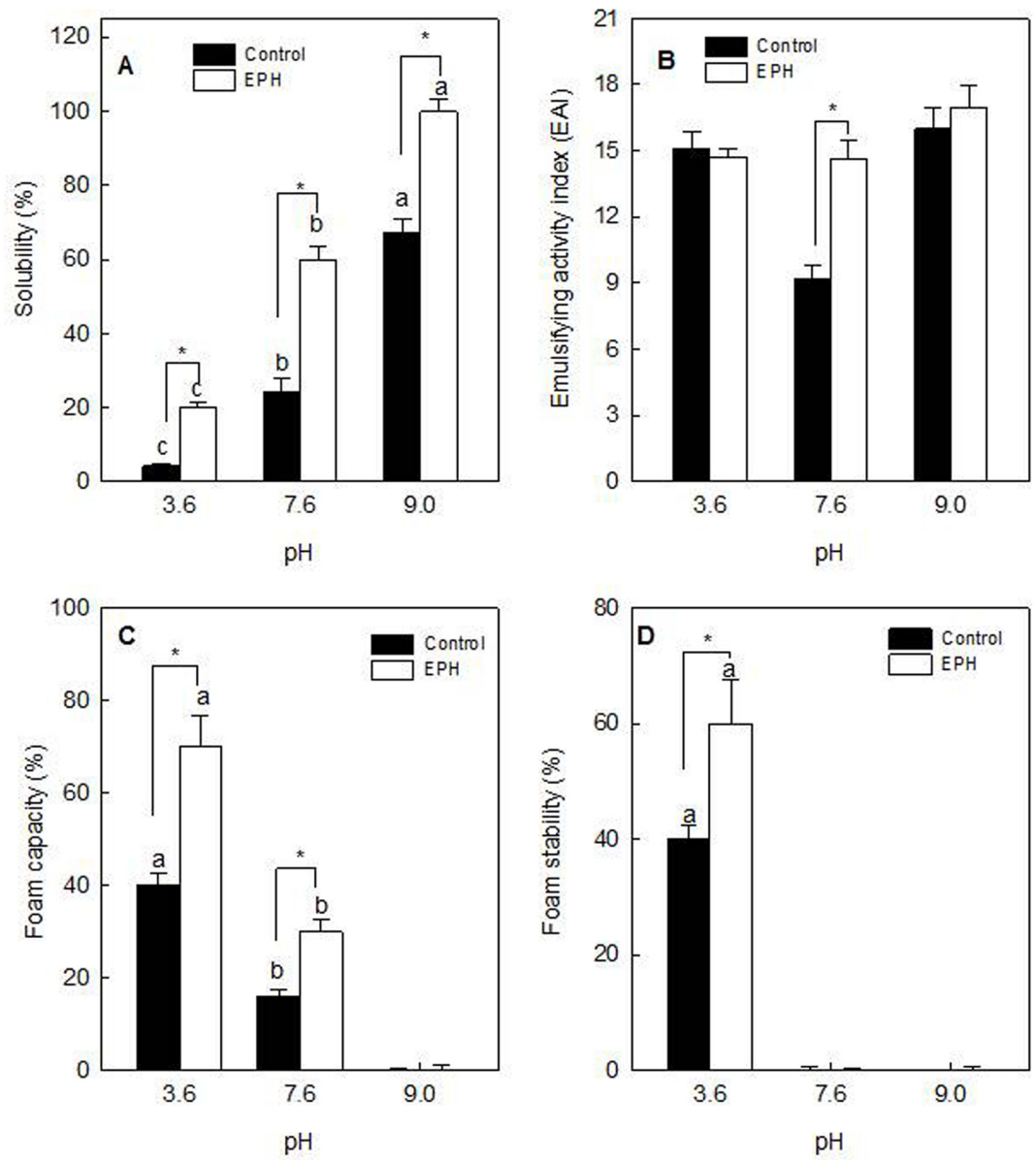

Fig. 5. Solubility (A), emulsifying activity index (B), foaming capacity (C), and stability (D) of Neutrase hydrolysate in different pHs. The hydrolysate was dissolved in $50 \mathrm{mM}$ citrate- $\mathrm{NaOH}$ buffer ( $\mathrm{pH}$ 3.6), phosphate buffer ( $\mathrm{pH}$ 7.6), and Tris- $\mathrm{HCl}$ buffer ( $\mathrm{pH}$ 9.0). Then, the solubility, EAI, FS, and FC were determined. These values are means \pm S.D. ${ }^{\mathrm{a}-\mathrm{c}}$ Different letters indicate significant differences with the same sample $(p<0.05)$. ${ }^{*}$ The differences between samples before and after enzyme hydrolysis were evaluated by Student's $t$-tests $(p<0.05)$.

Foaming capacity tended to decrease at pH 7.6 and 9.0. The foaming capacity of EPH reached a maximum at $\mathrm{pH}$ 3.6 and decreased at alkaline $\mathrm{pH}$. Neutrase hydrolysis also showed a significantly increase of foam capacity and foam stability compared with non-hydrolysis egg white liquid at $\mathrm{pH} 3.6(p<0.05)$.

Net charge influences the adsorption of proteins at the air-water interface. Therefore, the foaming property is enhanced with increase in the net charge (Sorgentini and Wagner, 2002; Townsend and Nakai, 1983). The lowest foaming levels seen for the proteins coincided with the lowest solubilities at their isoelectric $\mathrm{pH}$ (Kinsella, 1979). EPH foam stability was lowest at $\mathrm{pH} 7.6$ and 9.0. In order to form a foam, surface active agents, including proteins and peptides, must adsorb rapidly at the air-water interface, which reduces the surface tension during the transient stage of foam formation (Phillips et al., 1994). Dic- kinson (1989) and Mutilangi et al. (1996) suggested that the foaming capacity of protein was improved by making it more flexible, by exposing more hydrophobic residues, and by increasing capacity to decrease surface tension.

Protein digestion produces a variety of peptides with altered hydrophobicity, charge balance, and conformation as compared with the native molecule. Their reduced molecular weights make them more flexible for forming a stable interfacial layer and increasing the rate of diffusion to the interface. These features improve their foamforming properties (Groninger and Miller, 1975).

Hydrolysis could reduce the foaming stability because the more microscopic peptides do not have the strength needed to maintain stable foam (Shahidi et al., 1995). This increase of foam capacity after hydrolysis may make possible to expand further applications of dried egg white in food processing. 


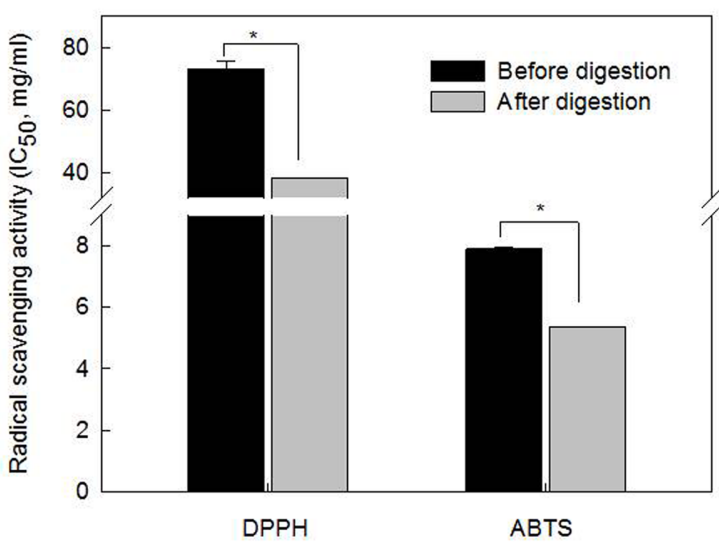

Fig. 6. Effect of neutrase digestion on DPPH and ABTS radical scavenging activities. These values are means \pm S.D. *The differences between samples before and after digestion were evaluated by Student's $t$-tests $(p<0.05)$.

\section{Radical scavenging activity of EPH before and after Neutrase treatment}

DPPH- and ABTS radical scavenging activities were significantly higher after enzymatic digestion (Fig. 6). Before digestion, the $\mathrm{IC}_{50}$ values for DPPH and ABTS radicals were 73.27 and $7.19 \mathrm{mg} / \mathrm{mL}$, respectively; after digestion, the $\mathrm{IC}_{50}$ values were 38.28 and $5.36 \mathrm{mg} / \mathrm{mL}$, respectively. Similarly, Sannaveerappa et al. (2008) reported that enzymatic breakdown of proteins from an aqueous herring extract under gastrointestinal-like conditions increased peroxyl radical scavenging activity and inhibited LDL oxidation.

Gastrointestinal digestion of food proteins by digestive enzymes or microbial enzymes from gut microflora (Möller et al., 2008) also produces peptides with antioxidant functions in the gut. These peptides activate receptors or cellsignaling pathways either locally or at distant sites in the body if the peptides can cross the epithelial cell membrane and enter the circulation. Oligopeptides, especially di- and tri-peptides, can be absorbed from the upper gastrointestinal tract depending on their structural characteristics.

The activities of preformed antioxidant hydrolysates and peptides may be altered while passing through the gastrointestinal tract. For example, Sheih et al. (2009) reported that the antioxidant peptide VECYGPNRPQF isolated from the microalga Chlorella vulgaris was resistant to gastrointestinal digestion. Antioxidant activity has been found to significantly increase upon simulated gastrointestinal digestion of Pacific hake protein hydrolysate and antioxidant peptides with molecular weights of 10003000 Da (Samaranayaka et al., 2010). Zhu et al. (2008) reported that zein hydrolysate, which was shown to have antioxidant activity (Kong and Xiong, 2006), displayed either increased or decreased antioxidant activity during in vitro digestion, depending on the enzymes and duration of hydrolysis. Therefore, peptide modification or breakdown during gastrointestinal digestion must be considered when evaluating food-derived antioxidant peptides for health-related purposes.

\section{Conclusion}

In addition to their nutritional value, hen eggs contain numerous substances with therapeutic effects. Several of these substances have already been produced on an industrial scale for food and medical applications. EPH may be a good source of desirable peptides and amino acids. Furthermore, it may be used as an emulsifier and foaming agent with antioxidant activities. EPH prepared with Neutrase is preferable to those prepared using other enzymes, as it had the highest radical scavenging activity. Ongoing research is aimed at identifying the active peptides and determining their individual radical scavenging activities. Moreover, continued identification of the biological functions of egg components will define new methods for improving the utility of eggs as a source of biologically active compounds with specific health benefits and secure their role in the treatment and prevention of disease.

\section{Acknowledgements}

This research was supported by Technology Development Program for Food, Ministry for Food, Agriculture, Forestry and Fisheries, Republic of Korea.

\section{References}

1. Adler-Nissen, J. (1979) Determination of the degree of hydrolysis of food protein hydrolysates by trinitrobenzenesulfonic acid. J. Agric. Food Chem. 27, 1256-1262.

2. Almajano, M., Carbo, R., Delgado, M., and Gordon, M. (2007) Effect of $\mathrm{pH}$ on the antimicrobial activity and oxidative stability of oil in water emulsions containing caffeic acid. $J$. Food Sci. 72, C258-C263.

3. Amarowicz, R. and Shahidi, F. (1997) Antioxidant activity of peptide fractions of capelin protein hydrolysates. Food Chem. 58, 355-359.

4. Anton, M., Nau, F., and Nys, Y. (2006) Bioactive egg components and their potential uses. Worlds Poult. Sci. J. 62, 429438.

5. Archer, M. C., Ragnarsson, J. O., Tannenbaum, S. R., and Wang, D. I. C. (1973) Enzymatic solubilization of an insolu- 
ble substrate, fish protein concentrate - process and kinetic considerations. Biotechnol. Bioeng. 15, 181-196.

6. Aspmo, S. I., Horn, S. J., and Eijsink, V. G. H. (2005) Enzymatic hydrolysis of Atlantic cod (Gadus morhua L.) viscera. Process Biochem. 40, 1957-1966.

7. Baek, H. H. and Cadwallader, K. R. (1995) Enzymatic-hydrolysis of crayfish processing by-products. J. Food Sci. 60, 929-935.

8. Benjakul, S. and Morrissey, M. T. (1997) Protein hydrolysates from Pacific whiting solid wastes. J. Agric. Food Chem. 45, 3423-3430.

9. Chen, C., Chi, Y. J., and Xu, W. (2012) Comparisons on the functional properties and antioxidant activity of spray-dried and freeze-dried egg white protein hydrolysate. Food Bioprocess Technol. 5, 2342-2352.

10. Davalos, A., Miguel, M., Bartolome, B., and Lopez-Fandino, R. (2004) Antioxidant activity of peptides derived from egg white proteins by enzymatic hydrolysis. J. Food Prot. 67, 1939-1944.

11. Edwards, J. and Shipe, W. (1978) Characterization of plastein reaction products formed by pepsin, $\alpha$-chymotrypsin, and papain treatment of egg albumin hydrolysates. J. Food Sci. 43, 1215-1218.

12. Groninger, H. S. and Miller, R. (1975) Preparation and aeration properties of an enzyme-modified succinylated fish protein. J. Food Sci. 40, 327-330.

13. Hill, S. (1996) Emulsions. In: Methods for Testing Protein Functionality. Hall, G. M. (ed) Blackie Academic \& Professional, London, pp. 153-182.

14. Hoyle, N. T. and Merritt, J. H. (1994) Quality of fish-protein hydrolysates from Herring (Clupea-harengus). J. Food Sci. 59, 76-79.

15. Jao, C. L. and Ko, W. C. (2002) 1,1-diphenyl-2-picrylhydrazyl (DPPH) radical scavenging by protein hydrolyzates from tuna cooking juice. Fish. Sci. 68, 430-435.

16. Jun, S. Y., Park, P. J., Jung, W. K., and Kim, S. K. (2004) Purification and characterization of an antioxidative peptide from enzymatic hydrolysate of yellowfin sole (Limanda aspera) frame protein. Eur. Food Res. Technol. 219, 20-26.

17. Kato, A., Ibrahim, H. R., Watanabe, H., Honma, K., and Kobayashi, K. (1989) New Approach to Improve the Gelling and Surface Functional-Properties of Dried Egg-White by Heating in Dry State. J. Agric. Food Chem. 37, 433-437.

18. Kinsella, J. E. (1979) Functional properties of soy proteins. J. American Oil Chemists' Soc. 56, 242-258.

19. Kong, B. H. and Xiong, Y. L. L. (2006) Antioxidant activity of zein hydrolysates in a liposome system and the possible mode of action. J. Agric. Food Chem. 54, 6059-6068.

20. Kong, X. Z., Zhou, H. M., and Qian, H. F. (2007) Enzymatic preparation and functional properties of wheat gluten hydrolysates. Food Chem. 101, 615-620.

21. Kristinsson, H. G. and Rasco, B. A. (2000) Fish protein hydrolysates: Production, biochemical, and functional properties. Crit. Rev. Food Sci. Nutr. 40, 43-81.

22. Li, Y. H., Jiang, B., Zhang, T., Mu, W. M., and Liu, J. (2008) Antioxidant and free radical-scavenging activities of chick- pea protein hydrolysate (CPH). Food Chem. 106, 444-450.

23. Li-Chan, E. and Nakai, S. (1990) Importance of hydrophobicity of proteins in food emulsions. In: Microemulsions and emulsions in foods. El-Nokaly, M. \& Cornell, D. (ed) ACS Publications, Washington, D.C. USA, pp. 193-212.

24. Linder, M., Fanni, J., and Parmentier, M. (1996) Functional properties of veal bone hydrolysates. J. Food Sci. 61, 712716.

25. Matsudomi, N., Ishimura, Y., and Kato, A. (1991) Improvement of Gelling Properties of Ovalbumin by Heating in Dry State. Agric. Biol. Chem. 55, 879-881.

26. Miguel, M., Alonso, M. J., Salaices, M., Aleixandre, A., and López-Fandiño, R. (2007) Antihypertensive, ACE-inhibitory and vasodilator properties of an egg white hydrolysate: Effect of a simulated intestinal digestion. Food Chem. 104, 163-168.

27. Miliauskas, G., Venskutonis, P. R., and van Beek, T. A. (2004) Screening of radical scavenging activity of some medicinal and aromatic plant extracts. Food Chem. 85, 231-237.

28. Mine, Y. (2007) Egg proteins and peptides in human healthchemistry, bioactivity and production. Curr. Pharm. Des. 13, 875-884.

29. Morr, C. V. (1985) Composition, physico-chemical and functional properties of reference whey protein concentrates. $J$. Food Sci. 50, 1406-1411.

30. Moure, A., Dominguez, H., and Parajo, J. C. (2006) Antioxidant properties of ultrafiltration-recovered soy protein fractions from industrial effluents and their hydrolysates. Process Biochem. 41, 447-456.

31. Möller, N. P., Scholz-Ahrens, K. E., Roos, N., and Schrezenmeir, J. (2008) Bioactive peptides and proteins from foods: indication for health effects. Eur. J. Nutr. 47, 171-182.

32. Mutilangi, W. A. M., Panyam, D., and Kilara, A. (1996) Functional properties of hydrolysates from proteolysis of heatdenatured whey protein isolate. J. Food Sci. 61, 270-275.

33. Pearce, K. N. and Kinsella, J. E. (1978) Emulsifying properties of proteins: evaluation of a turbidimetric technique. $J$. Agric. Food Chem. 26, 716-723.

34. Pena-Ramos, E. A. and Xiong, Y. L. L. (2003) Whey and soy protein, hydrolysates inhibit lipid oxidation in, cooked pork patties. Meat Sci. 64, 259-263.

35. Peng, X. Y., Xiong, Y. L. L., and Kong, B. H. (2009) Antioxidant activity of peptide fractions from whey protein hydrolysates as measured by electron spin resonance. Food Chem. 113, 196-201.

36. Phillips, L. G., Whitehead, D. M., and Kinsella, J. E. (1994) Structure-function properties of food proteins. Academic Press.

37. Quaglia, G. and Orban, E. (1987) Enzymic solubilisation of proteins of sardine (Sardina pilchardus) by commercial proteases. J. Sci. Food Agric. 38, 263-269.

38. Quang, D. N., Hashimoto, T., Nukada, M., Yamamoto, I., Tanaka, M., and Asakawa, Y. (2003) Antioxidant activity of curtisians I-L from the inedible mushroom Paxillus curtisii. Planta Med. 69, 1063-1066.

39. Raghavan, S., Kristinsson, H. G., and Leeuwenburgh, C. (2008) Radical Scavenging and Reducing Ability of Tilapia 
(Oreochromis niloticus) Protein Hydrolysates. J. Agric. Food Chem. 56, 10359-10367.

40. Sakanaka, S., Tachibana, Y., Ishihara, N., and Juneja, L. R. (2004) Antioxidant activity of egg-yolk protein hydrolysates in a linoleic acid oxidation system. Food Chem. 86, 99-103.

41. Samaranayaka, A. G., Kitts, D. D., and Li-Chan, E. C. (2010) Antioxidative and angiotensin-I-converting enzyme inhibitory potential of a Pacific hake (Merluccius productus) fish protein hydrolysate subjected to simulated gastrointestinal digestion and Caco-2 cell permeation. J. Agric. Food Chem. 58, 1535-1542.

42. Sannaveerappa, T., Carlsson, N. G., Sandberg, A. S., and Undeland, I. (2008) Antioxidative properties of press juice from herring (Clupea harengus) against hemoglobin ( $\mathrm{Hb})$ mediated oxidation of washed cod mince (vol 55, pg 9581, 2007). J. Agric. Food Chem. 56, 1795-1795.

43. Sathe, S. and Salunkhe, D. (1981) Functional properties of the great northern bean (Phaseolus vulgaris L.) proteins: Emulsion, foaming, viscosity, and gelation properties. J. Food Sci. 46, 71-81.

44. Shahidi, F., Han, X. Q., and Synowiecki, J. (1995) Production and characteristics of protein hydrolysates from Capelin ( $M a-$ llotus-villosus). Food Chem. 53, 285-293.

45. Sheih, I., Wu, T. K., and Fang, T. J. (2009) Antioxidant properties of a new antioxidative peptide from algae protein waste hydrolysate in different oxidation systems. Bioresour. Technol. 100, 3419-3425.

46. Shen, J. L. (1976) Solubility profile, intrinsic viscosity, and optical rotation studies of acid precipitated soy protein and of commercial soy isolate. J. Agric. Food Chem. 24, 784-788.

47. Sorgentini, D. A. and Wagner, J. R. (2002) Comparative study of foaming properties of whey and isolate soybean proteins. Food Res. Int. 35, 721-729.

48. Suetsuna, K. (2000) Antioxidant peptides from the protease digest of prawn (Penaeus japonicus) muscle. Mar. Biotechnol. 2, 5-10.

49. Townsend, A. A. and Nakai, S. (1983) Relationships between hydrophobicity and foaming characteristics of food proteins.

J. Food Sci. 48, 588-594.

50. Turgeon, S. L., Gauthier, S. F., and Paquin, P. (1991) Interfacial and emulsifying properties of whey peptide fractions obtained with a two-step ultrafiltration process. J. Agric. Food Chem. 39, 673-676.

51. Xie, Z. J., Huang, J. R., Xu, X. M., and Jin, Z. Y. (2008) Antioxidant activity of peptides isolated from alfalfa leaf protein hydrolysate. Food Chem. 111, 370-376.

52. Wang, H. C., Chen, C. R., and Chang, C. J. (2001) Carbon dioxide extraction of ginseng root hair oil and ginsenosides. Food Chem. 72, 505-509.

53. Wang, L. L. and Xiong, Y. L. L. (2005) Inhibition of lipid oxidation in cooked beef patties by hydrolyzed potato protein is related to its reducing and radical scavenging ability. $J$. Agric. Food Chem. 53, 9186-9192.

54. Wu, H. C., Chen, H. M., and Shiau, C. Y. (2003) Free amino acids and peptides as related to antioxidant properties in protein hydrolysates of mackerel (Scomber austriasicus). Food Res. Int. 36, 949-957.

55. Zhu, L. J., Chen, J., Tang, X. Y., and Xiong, Y. L. (2008) Reducing, radical scavenging, and chelation properties of invitro digests of alcalase-treated zein hydrolysates. J. Agric. Food Chem. 56, 3884-3884.

(Received 2014.4.1/Revised 2014.5.15/Accepted 2014.5.19) 